\title{
NOTES AND REVIEWS
}

\section{THE ARCTIC COUNCIL OF 1851}

In 1848, when no news of Sir John Franklin's expedition of 1845 had reached England, alarm began to manifest itself for the fate of the missing men. In that year the first of the long series of search expeditions set out. By 1851 the plans of these expeditions were placed in the hands of the "Arctic Council", appointed by the Admiralty and consisting of the most prominent "Arcticists" of the period.

To mark the centenary of the formation of this Arctic Council, we reproduce an engraving after the painting by Stephen Pearce, showing this group of experts. Brief notes on their previous careers are added.

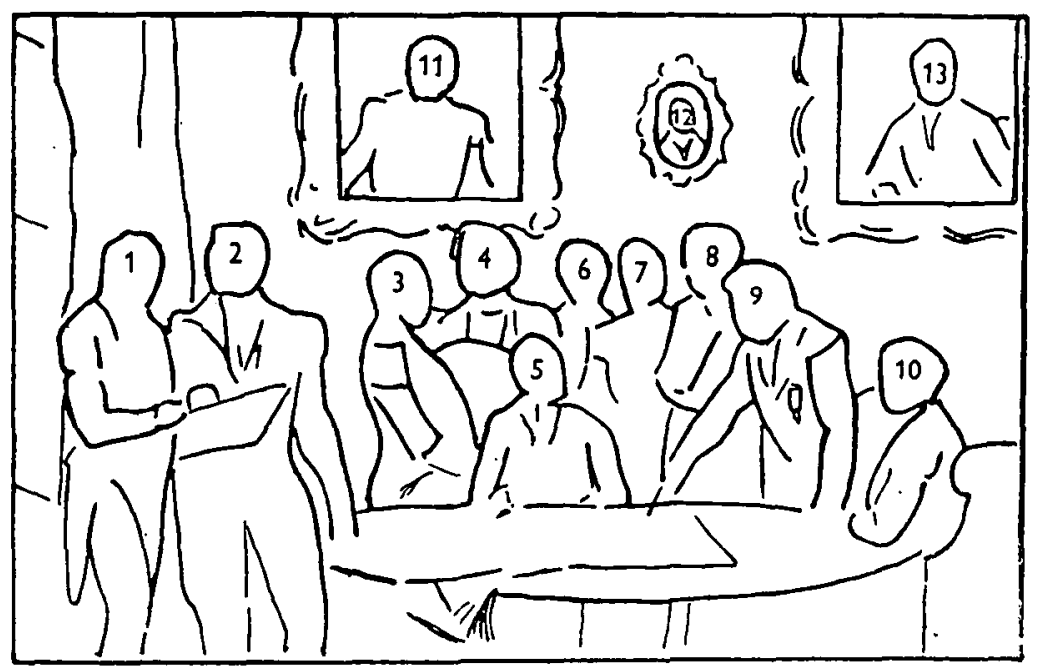

Key to the engraving

1 Sir George Back, F.R.S.

2 Sir William Edward Parry, F.R.S.

3 Captain Edward J. Bird

4 Sir James Clark Ross, F.R.S.

5 Sir Francis Beaufort, K.C.B., F.R.S.
6 John Barrow, Esq., F.R.S., F.S.A.

7 Lieutenant-Colonel Sabine, R.A., V.P.R.S.

8 Captain W. A. Baillie Hamilton

9 Sir John Richardson, C.B., F.R.S.

10 Captain F. W. Beechey, F.R.S.

11 Sir John Franklin, K.C.F., F.R.S.

12 Captain James Fitzjames

13 Sir John Barrow, Bart., F.R.S.

On the occasion of the first publication of this print in 1851, a "descriptive key" was provided by W. R. O'Byrne, which opens with the words:

At a moment like the present, when Great Britain, joined by Representatives of the Maritime Powers of France, Russia, and the United States of America, is making 
the most noble efforts for the recovery of Sir John Franklin and his gallant companions, and when, with the deepest interest and anxiety, the whole of the civilized world is looking for tidings of the lost Navigator, it has been considered not inopportune to submit to the inspection of the public a picture containing authentic portraits of the great Arctic Officers now among us, who have all won their laurels on the icy field, and many of whom have shared with Franklin the hardships and perils of his former voyages. Apart from the personal interest which attaches to the extraordinary fidelity, in character and expression, of the likenesses, the scene in which the actors are represented-for they are discussing the measures best to be adopted for the recovery of their absent brother officers and friends-will ever impart to the painting a two-fold value. ${ }^{1}$

1. Captain Sir George BAck entered the Royal Navy at the age of eleven in 1807, and languished as a prisoner-of-war in French hands from 1809 to 1814. He began his polar career in 1818 when serving under Lieutenant John Franklin in the brig Trent, which accompanied H.M.S. Dorothea, Captain David Buchan, on a voyage of discovery to the neighbourhood of Spitsbergen. On his return from Spitsbergen Back was selected as a member of Franklin's overland expedition from Hudson Bay to the mouth of the Coppermine River in the years 1819 to 1822 . During this expedition, which covered a total distance of some $\mathbf{5 5 5 0}$ miles, Back made a winter journey on foot from Fort Enterprise to Fort Chipewyan and return, a distance of 1104 miles. From 1825 to 1827 he again accompanied Franklin on a second overland expedition to the shores of the Arctic Ocean, reaching long. $149^{\circ} 37^{\prime} \mathrm{W}$. in lat. $70^{\circ} 24^{\prime} \mathrm{N}$. In 1833 Back, now a commander, was appointed to lead an overland expedition to search for Sir John Ross, who had sailed four years previously in quest of a North-West Passage. It was on this journey that Back discovered the source of the Great Fish River (now Back River). On his return to England in 1835 he was promoted captain, and in the following year was given command of the Terror bomb, and sent to explore towards the Wager River. The Terror was, however, badly. damaged in the ice at tine entrance of Frozen Strait, and Back returned to Lough Swilly with his vessel frapped together with the stream-chain cable.

2. Captain Sir William Edvard Parry entered the Royal Navy in 1803 at the age of thirteen. His first appointment after his promotion to the rank of lieutenant in 1810 was to the Alexandria, then engaged in protecting the Spitsbergen whale-fishery. He later served in America during the war against the United States. In 1818 he obtained command of the Alexander brig and took part in Captain John Ross's arctic expedition of that year. In the following year Parry was appointed leader of a new expedition to discover a North-West Passage, in the Hecla bomb and Griper gun-brig. The expedition sailed from Deptford in May 1819 and succeeded in penetrating Lancaster Sound and Barrow Strait as far as long. $113^{\circ} 64^{\prime} 43^{\prime \prime} \mathrm{W}$. The expedition thereby obtained the parliamentary award of $£ 5000$, promised to the

1 The Arctic Council discussing the plain of search for Sir John Franklin for submission to the Lords of the Admiralty. An historical picture painted by Stephen Pearce, Esq. To be engrazed in the finest style of att and dedicated to Lady Franklin. The descriptive key by W.R. O'Byrne, Esq., author of "The naval biography". London : Henry Graves and Company, 1851. 
first to cross the meridian of long. $110^{\circ} \mathrm{W}$. within the Arctic Circle. The Hecla and Griper returned home in November 1820. In the following year Parry, with the rank of commander, received a commission for the Fury bomb, which together with the Hecla sailed in May 1821 in search of a NorthWest Passage. The expedition passed two winters in Foxe Basin, and returned to England late in 1823. In 1824 he again led an expedition in the Hecla and Fury to the Canadian Arctic. The winter of 1824-25 was spent in Prince Regent Inlet, but the Fury was badly damaged and had to be abandoned. The Hecla returned to England carrying a double ship's company. Parry's last arctic venture was an expedition in 1827 towards the North Pole from a base in Spitsbergen. The Hecla was left in Sorgfjorden (Treurenberg Bay) and a party with two "sledge-boats" contrived to travel northwards on the polar pack, reaching lat. $82^{\circ} 45^{\prime} \mathrm{N}$., long. $19^{\circ} 25^{\prime} \mathrm{E}$., the most northerly latitude then attained.

3. Captain Edward Joseph Bird served under Parry as mate of the Hecla in 1821-23 and of the Fury in 1824-25. In 1827 he again accompanied Parry in the Hecla, and took part in the northern sledge-boat journey. He was later appointed to the Erebus bomb and was a member of Captain James Clark Ross's antarctic expedition of 1839-43. In 1848-49 Bird commanded the Investigator, which was sent with Sir James Clark Ross in the Enterprise to search for Franklin.

4. Captain Sir JAMES ClaRK Ross was born in 1800 and entered the Royal Navy in 1812. He first served in the Baltic, White Sea, and in home waters. In 1818 he was placed under the orders of his uncle Captain John Ross as midshipman on board the Isabella sloop, and took part in that officer's first expedition in search of a North-West Passage. From January 1819 to October 1825 he served on Parry's three expeditions, and was lieutenant on board the Fury when that vessel was wrecked in 1825. In 1827 he was first lieutenant of the Hecla and accompanied Parry on the northern sledge-boat journey. He was promoted commander in that year and from 1829 to 1833 again served with his uncle on the arctic expedition equipped by Sir Felix Booth. During this expedition Ross planted the British flag on the North Magnetic Pole. After the abandonment of the Victory in Boothia Felix and the return of the expedition to England he was advanced to the rank of captain. In December 1835 he was appointed to command the Cove with the task of relieving missing whalers in Baffin Bay. In April 1839 he received the command of the antarctic expedition in the Erebus and Terror bombs, which sailed that year for the purposes of magnetic research and geographical exploration. In the course of the next four years the expedition, which attained a furthest south point in lat. $78^{\circ} 10^{\prime}$, discovered Victoria Land. The expedition returned in September 1843. In January 1848 Ross was appointed to the Enterprise, and sent in charge of an expedition consisting of that vessel and the Investigator in search of the Franklin expedition.

5. Rear-Admiral Sir Francis Beaufort entered the Royal Navy in 1787 and served with distinction in the wars against France from 1792 to 1815 . On the occasion of his capture of the Spanish man-of-war San Josef at Fuengirola 
in October 1800, he was severely wounded, and was rewarded with a commander's commission. In $\mathbf{1 8 1 0}$ he was given command of the Frederickstein frigate, surveying the coast of Asia Minor for two years, when he was again severely wounded, this time by a fanatical Turk. For several years after his return to England he was working on the results of his marine surveys. $\mathrm{He}$ became Hydrographer of the Admiralty in 1832 and was promoted rearadmiral in 1846.

6. JoHN Barrow, the second son of Sir John Barrow, "was placed by his father in the Admiralty, where, by close and unremitting devotion to his duties, he has risen through different grades to the important position he now fills, endeared by the kindliness of his nature and the urbanity of his manners to all who have had the good fortune to be brought into contact with him, and honoured on repeated occasions with the acknowledgements of the board, for his laborious and extensive classification and arrangement of the records and documents in his department". 1

In early life a keen traveller, he shared his father's enthusiasm for scientific research and arctic discovery:

Since the commencement of the anxiety which prevails with regard to the fate of Sir John Franklin, he has unceasingly directed his energies to the furtherance of every searching expedition that has been started, and by his exertions has earned the affection and gratitude, not only of those who have so nobly embarked in the different enterprises, but of every well-wisher to the cause of humanity. To Lady Franklin, whose devoted and extraordinary efforts for the recovery of her husband and his gallant companions have proved the theme of universal admiration, he has ever shown himself a ready friend and faithful counsellor. ${ }^{2}$

7. Lieutenant-Colonel Edward Sabine, R.A., obtained his first commission in the Royal Artillery at the age of fifteen. He served in Canada from 1813 to 1816 , and for his services on the Niagara frontier in 1814 was directed by the Master General of the Ordnance to wear the word "Niagara" on his dress and appointments. In 1818 and again in 1819 he accompanied the arctic expeditions led by Captain John Ross and Captain Parry, serving in the capacity of astronomer. In 1821, 1822 and 1823 he served aboard H.M. ships Pheasant and Griper, conducting a series of pendulum experiments, and visiting various points on the coasts of Africa, America, East Greenland, Spitsbergen and Norway. After that period, with the exception of seven years spent on regimental and staff duties, he devoted himself to scientific pursuits as an officer of the Royal Society and the British Association for the Advancement of Science.

8. Captain William Alexander Baillie Hamilton was born in 1803 and entered the Royal Navy in 1816. He was promoted to the rank of lieutenant in 1823 and later served in the Mediterranean for many years. He acted as his relative Lord Haddington's private secretary when that nobleman became First Lord of the Admiralty in 1841, and in January 1845, "having in the meantime, by the manner in which he discharged the duties of his delicate and

1 Idem, p. 25. 
important post, acquired the affection and esteem of the service to an extent unparalleled, he was selected to succeed the late lamented Sir John Barrow, Bart., in the second Secretaryship of the Admiralty". 1

9. Sir John Richardson was born in 1787 and studied medicine at the University of Edinburgh. In April 1807 he entered the Royal Navy as surgeon, and after wide service in the wars against France and the United States he returned to study medicine, natural philosophy and natural history at Edinburgh. From 1819 to 1822 , and again from 1825 to 1827 , he was surgeon and naturalist with Franklin's two overland expeditions to the shores of the Arctic Ocean. On the latter occasion he commanded the two boats which surveyed the coast between Mackenzie River and Coppermine River. In 1838 he was promoted to the rank of Physician to the Fleet, and in 1840 became Inspector of Hospitals and Fleets. In 1850 he was sent in command of a Franklin Search expedition overland to the north coast of America.

10. Captain Frederick Wildiam Beechey entered the Royal Navy at the age of ten and served in the wars against France and the United States. In 1818 he was appointed to the Trent brig, commanded by Franklin, and took part in Buchan's expedition to Spitsbergen. In the following year he accompanied Parry's first arctic expedition. In 1821-22 he was engaged on a land survey of the northern coast of Africa from Tripoli eastwards. In 1825 he was appointed to command the Blossom and sent round Cape Horn to Bering Strait, there to act in conjunction with the contemporaneous expeditions of Franklin and Parry in search of a North-West Passage. In August 18:26 the Blossom's barge, under Thomas Elson, master, reached Point Barrow in lat. $71^{\circ} 23^{\prime} \mathrm{N}$., long. $156^{\circ} 21^{\prime} \mathrm{W}$., only 146 miles from the farthest point reachcd by Franklin when exploring westwards from the Mackenzie River delta in 1826. The Blossom finally returned to Spithead in 1828, having completed a voyage of 73,000 miles. Beechey later went to South America with the Sulphur survey vessel and from 1837 was employed in surveying the Irish coasts.

\section{ICE WORMS}

Attention has recently been directed to the occurrence of these Oligochaetcs by a letter from N. E. Odell to Nature ${ }^{5 *}$ and by notices in the press. Odell reports that he found a considerable number on Seward Glacier in August 1949, during Project "Snow Cornice". See the Polar Record, Vol. 6, No. 41, 1951, p. 97-99.)

In $1930 \mathrm{~J}$. Stephenson ${ }^{10}$ summarized the information available up to that date, quoting, inter alia, the authors mentioned by Odell (P. S. Welch ${ }^{12}$; I. C. Russell ${ }^{7}$; C. Emery ${ }^{1}$ ). Most of the records undoubtedly come from North America and most of the specimens are referred to the species Mesenchytraeus solifugus. These accounts, however, differ from that of Odell since (as its specific name implies) this species is considered to be negatively phototactic, appearing on the surface of the snow in the late afternoon and retreating

1 Idem. p. 27.

* For references see p. 391. 